\title{
Heavy metals and organochlorinated compounds in the European eel (Anguilla anguilla) from the Adour estuary and associated wetlands (France)
}

\author{
Tabouret $^{1,2}$, H., Bareille ${ }^{2, *}$, G., Mestrot ${ }^{2}$, A., Caill-Milly ${ }^{1}$, N., Budzinski ${ }^{3}$, H., Peluhet $^{3}$, L., Prouzet $^{1}$, P., \\ Donard ${ }^{2}$, O.F.X.
}

\footnotetext{
${ }^{1}$ IFREMER Laboratoire des Ressources Halieutiques d'Aquitaine, UFR côte Basque, 1 Allée du Parc Montaury, 64600 Anglet, France.

${ }^{2}$ Laboratoire de Chimie Analytique Bio-inorganique et Environnement, IPREM - UMR 5254 CNRS, Université de Pau et des Pays de l'Adour - Hélioparc Pau Pyrénées, 2, av. P. Angot, 64053 Pau Cedex 9, France.

${ }^{3}$ Université de Bordeaux 1 - CNRS, Laboratoire de Physico- et Toxico-Chimie de l'environnement (LPTC), Environnements et Paléoenvironnements Océaniques et Continentaux (EPOC- UMR 5805 CNRS -, 351 cours de la Libération 33405 Talence Cedex, France.
} *Corresponding author: G. Bareille, Tel : +33(0)5 594077 61, email address : gilles.bareille@univ-
pau.fr

\begin{abstract}
:
Heavy metals and organic pollutants were investigated in the Adour estuary (South West France) and associated wetlands using the European eel (Anguilla anguilla) as a bioindicator. Heavy metals $(\mathrm{Cu}, \mathrm{Cd}, \mathrm{Zn}, \mathrm{Pb}$, and $\mathrm{Ag}$ ) were measured in soft tissue of yellow eels. Mercury (total $\mathrm{Hg}$ and $\mathrm{MeHg}$ ) and organochlorinated compounds (7 PCBs, 11 OCPs) were analysed in muscle. Concentrations in muscle were in agreement with moderately contaminated environments in Europe and were below the norms fixed for eel consumption for heavy metals and OCPs. Analyses of liver showed a higher pressure of $\mathrm{Ag}$ and $\mathrm{Zn}$ in the downstream estuary than in the freshwater sites whereas $\mathrm{Cd}$ was lower in the estuary probably because of the salinity influence. According to quality classes $100 \%$ of eels from freshwater sites indicated clean or slightly polluted environments. However, total mercury concentrations were close to the thresholds fixed by the European Community in the downstream estuary, whereas the sum of PCBs was found to be greatly above the fixed value. $100 \%$ of the individuals from the estuary were classified in quality classes corresponding to polluted or highly polluted sites. These first results highlight the need of further investigations focused on mercury and PCBs in this area taking the seasonal temperature influence into account for a better understanding of the pollution distribution and the possible threat on the eel population from the Adour basin.
\end{abstract}




\section{Introduction}

Heavy metals and organochlorinated compounds (Polychlorinated Compounds PCBs, Organochlorine pesticides OCPs) are omnipresent in hydrosystems as a consequence of the daily anthropogenic activities and the persistence of some compounds used in the past. The detection and evaluation of the influence of hazardous chemicals is of growing concern because of the potential threat they represent for wildlife and human health by inducing a wide range of adverse effects. In 2000, the European commission edited the Water Framework Directive aiming at restoring aquatic sites to a sound ecological state by 2015 and leading the scientific research to evaluate the basal state of each system through the development and use of relevant indicators. Biological indicators such as bivalves (oysters, mussels), crustacean or fish are commonly used to evaluate the chemical state of aquatic environments ${ }^{1,2,3}$.

A number of studies supported the use of eels as reliable bioindicators of environmental changes ${ }^{4,5}$ and contaminant concentrations in eel tissue as suitable indicators reflecting the environmental exposure to pollutants ${ }^{2,6,7,8}$. The EIFAC/ICES Working Group on Eels $^{9}$ and the Scientific, Technical, and Economic Committee for Fisheries ${ }^{10}$ have recommended that the Water Framework Directive should use the eel (Anguilla anguilla) as a sentinel species for monitoring the chemical status of surface waters with respect to hazardous substances. The choice of this indicator is based on the physiological and behavioural characteristics of eels and especially the yellow eel phase. Yellow eels are immature and studies should not be confused by the influence of sexual maturation. They are widely distributed in every kind of aquatic habitat ${ }^{11,12}$. In addition, yellow eels are carnivorous, exhibit high lipid content ${ }^{13}$ and benthic behaviour making this species prone to bioaccumulate a wide diversity of compounds including lipophilic and persistent ones ${ }^{14,15}$. Even if seasonal migrations and nomadic movements were highlighted ${ }^{12,16,17}$, they are relatively sedentary through their growth phase period ranging from 3 to 18 years or more. Eels also show a resistance to physico chemical stress ${ }^{13}$ and a life-long accumulation and low depuration ${ }^{18,19}$ giving them the ability to accumulate pollutants and reflect the environmental signature transmitted by water, sediment and prey.

In addition, eels also represent a vector of the exposure to heavy metals and persistent organochlorinated compounds from human population ${ }^{20}$. Using eels as a bioindicator is concomitant with the evaluation of the contribution of chemical pressure on the high decline of this species since the $1980 \mathrm{~s}^{21,22}$. In 2007, a European Eel Quality Database (EEQD) was set up to collate information on contamination in eels over Europe ${ }^{23,24}$. Reports from the literature 
support the potential impact of heavy metals on respiration, osmoregulation due to gill alteration by $\mathrm{Hg}$ for example, or kidney injuries, blood anaemia and disturbances of carbohydrate metabolism by $\mathrm{Cd}$. Heavy metal exposure could also lead to an increased susceptibility of eels to pathogenic organisms ${ }^{25}$. Recently, Robinet and Feunteun ${ }^{26}$ and Geerarts and Belpaire ${ }^{27}$ reported the potential disturbances caused by several compounds on the immune system, endocrine system, reproduction and at different scales of biological organization (subcellular, organ, individual, population).

At a local scale, eel has been shown to be one of the dominant species of the fish community that greatly participates in the local fishery industry and economy of the Adour basin (south west, France). This species, and especially the glass eel phase, is vital for the fishery industry since it represents $66 \%$ of the total catch value ${ }^{28}$. Recent investigations described the Adour estuary as moderately contaminated ${ }^{29,30,31}$, however data on the associated wetlands are scarce.

In this article we present the first investigation of the bioaccumulation of heavy metals $(\mathrm{Cu}, \mathrm{Zn}, \mathrm{Cd}, \mathrm{Pb}$ and $\mathrm{Ag})$, mercury and organochlorinated compounds (7 PCBs and $11 \mathrm{OCPs}$ ) in soft tissue of the European yellow eels (Anguilla anguilla, L.) from the Adour estuary, a small macrotidal estuary, and its associated wetlands. We intend to evaluate the pressure of metal and organochlorinated compounds (PCBs and OCPs) endured by European yellow eels (Anguilla anguilla, L.) and the potential sanitary risk of eel consumption.

\section{Material and methods}

\subsection{Eel sampling sites and procedures}

The sampling strategy was based on previous population dynamic studies performed by Ifremer-LRHA ${ }^{32}$. Sampling periods were determined according to various phases characterizing the annual biological cycle of A. anguilla - colonization (from October to March) - sedentarisation (from January to September) - downstream migration (from October to December). Three periods of sampling corresponding approximately to the months of April, July and October were selected to cover these three main phases and investigate the seasonal influence on the bioaccumulation especially in the wetlands.

Eels were collected on three sites on the Adour basin (Fig. 1), one located within the urban and industrial zone of the downstream estuary (Redon) and two on wetland areas (St Laurent de Gosse - SLG and Termi) situated at the maximum saline intrusion limit. The 
Redon site, downstream estuary, is located close to the estuary mouth, and is under the influence of anthropogenic activities and physico-chemical processes linked to the mixing of freshwater and seawater. This site was only sampled twice, in July 2005 and July 2007, dates for which 15 and 5 specimens respectively were collected by eel pot by professional fishermen. For the two freshwater sites, individual eels were caught by electrofishing. A total of 21 yellow eels were collected at St Laurent de Gosse (SLG) on three dates, October 2005, July 2006 and May 2007. No eel was found at this site in May 2006, probably because of the dredging of the canal in April. Despite a recolonization of this site in July 2006, sampling also failed in October 2006 and July 2007. This site corresponds to a canal situated on the right river bank within the fluvial tidal zone of the estuary and is directly connected to the Adour estuary by valves. As a result, its downstream part is largely influenced by mixed estuarine fluvial waters and limited agricultural activities especially corn cultures. In its upstream portion, this canal crosses peat bogs and forest areas. The second wetland site (Termi) is a small canal on the left river bank, situated outside the tidal influence and shows brook characteristics. At this site, 51 individuals were sampled during five sampling periods from April 2006 to July 2007. After collection and allometric measurements (length in cm, weight in g), individuals were immediately frozen and stored at $-20^{\circ} \mathrm{C}$ in polyethylene bags until dissection and analysis. Liver, gills and muscle were removed from the eel body, weighted and freeze-dried $\left(48 \mathrm{~h},-45^{\circ} \mathrm{C}\right)$. They were weighted in order to determine the moisture content and then homogenized, finely ground in an agate mortar and split into several aliquots for the heavy metals, mercury compounds, PCB and OCP analyses. Clean methods were applied throughout dissection, preparation and analysis by using nitric acid-washed instruments, wearing latex gloves and using 18.2 M $\Omega \mathrm{MQ}$ water at all stages of the processes to minimize possible exogenous contamination.

\subsection{Chemical analysis of eel soft tissue}

Tissue samples were analyzed for 7 PCBs, 11 OCPs, 5 heavy metals $(\mathrm{Cu}, \mathrm{Zn}, \mathrm{Cd}, \mathrm{Pb}$ and Ag) and mercury compounds (total and methylmercury). Organochlorinated compounds were analyzed at the Laboratoire de Physico-Toxico Chimie des Systèmes Naturels, University of Bordeaux I (France), whereas heavy metals and mercury compounds were analyzed at the Laboratoire de Chimie Analytique Bio-inorganique et Environnement, University of Pau (France). Heavy metals were investigated in almost all soft tissues samples of each eel whereas only a couple of selected muscle samples (Table 1) were measured for 
organic compounds and mercury speciation. PCBs and OCPs were determined at three sites, the downstream estuary and the two wetland areas. For mercury concentrations and speciation only two sites were investigated, the downstream estuary and one wetland area, SLG site. Procedures and results relative to mercury compounds are explained elsewhere ${ }^{33}$. Statistical treatment was performed by Xlstat-Pro 7.5.2 (Addinsoft, France) using non parametrical Kruskall-Wallis test and Mann-Whitney $U$ test.

\section{Determination of heavy metals}

Around $200 \mathrm{mg}$ of freeze-dried homogenized and finely ground powder of muscle, liver or gills were placed in a $50 \mathrm{ml}$ vessel (Digiprep, SCP Sciences). $2 \mathrm{ml}$ Instra pur $\mathrm{HNO}_{3}$ (J.T. Baker) was then added and left to react overnight. After $24 \mathrm{~h}, 1 \mathrm{ml}$ of $\mathrm{H}_{2} \mathrm{O}_{2}$ was added and the whole preparation was placed on a heating system (Digiprep, SCP Sciences) where the digestion occurred according to specific temperature conditions, first an increase from $20^{\circ} \mathrm{C}$ to $80^{\circ} \mathrm{C}$ in 30 minutes, then $80^{\circ} \mathrm{C}$ for 120 minutes. The sample was then completely dried at $75^{\circ} \mathrm{C}$ for at least 30 minutes. Once cooled, $10 \mathrm{ml}$ of $2 \% \mathrm{HNO}_{3}$ Ultrex (J.T. Baker) were added to completely dissolve the residue and then stocked in a $10 \mathrm{ml}$ clean tube. The concentration of 5 elements $(\mathrm{Cu}, \mathrm{Zn}, \mathrm{Cd}, \mathrm{Pb}, \mathrm{Ag})$ was analyzed by means of an Inductively Coupled Plasma Mass Spectrometer (ICP-MS) Elan 6000 (Perkin Elmer). All measurements were carried out in duplicate and values were averaged. Two procedural blanks were processed within each series according to the sample procedure. The Certified Reference Materials (CRM) DOLT-3 Dogfish liver (CNRC, Canada) and DORM-2 Dogfish muscle (CNRC, Canada) were used to check the accuracy of measurements. Concentrations are expressed in ng.g ${ }^{-1}$ wet weight basis (ww). Limits of detection (LD) were Cu: $61 \mathrm{ng}^{-\mathrm{g}^{-1}}$; $\mathrm{Zn}$ : 1123 ng. $\mathrm{g}^{-1}$; Ag: 0.5 ng. $\mathrm{g}^{-1}$; Cd: 0.5 ng. $\mathrm{g}^{-1}$; Pb: $0.5 \mathrm{ng} . \mathrm{g}^{-1}$. Accepted recovery of reference material ranged from $82 \%$ to $122 \%$.

\section{Determination of $\mathrm{PCB}$ and $\mathrm{OCPs}$}

The 7 congeners considered as indicator PCBs $(28,52,101,118,153,138,180)$ were targeted. These 7 congeners are predominantly present in biotic and abiotic matrices and thus were recognized as compounds representative of the whole group of PCBs by the ATSDR (Agency for Toxic Substances and Disease Registry). The sum of these seven indicator PCBs $\left(\sum \mathrm{PCB}\right)$ was also calculated as it is commonly used in national legislation to ensure food safety $^{34}$. 11 persistent organochlorinated compounds (POCs: lindane, HCB, Heptachlor, 2,4' 
DDE, Cis and Trans Chlordane, Trans Nonachlor, 4,4' DDE, 2,4' DDD, 4.4'DDD, 2,4'DDT, 4,4' DDT) were also researched.

$0,5 \mathrm{~g}$ of homogenized freeze-dried sample was extracted for determination of PCB and OCP compounds using accelerated solvent extraction with on-line acid purification and cleanup on an acidic silica gel column performed by the ASE 200 system (Dionex) ${ }^{35}$. After extraction, the sample was collected and reconcentrated into $300 \mu 1$ of isooctane, using a RapidVap vacuum evaporation system from Labconco (Kansas City, MO, USA). A second purification of the extract was subsequently performed and the extract was put on an acidic silica gel column. The PCB and OCP compounds were eluted with $3 \times 5 \mathrm{ml}$ of a pentanedichloromethane mixture $(90: 10 \mathrm{v} / \mathrm{v})$. The extract was concentrated and transferred to isooctane. Analyses were carried out on an HP 5890 series II gas chromatograph from Hewlett-Packard (Avondale, CA, USA) coupled to a ${ }^{63} \mathrm{Ni}$ electron capture detector (ECD). A capillary column HP5-MS (Agilent Technologies, Massy, France) was used (30m x 0.25mm x $0.25 \mu \mathrm{m}$ ) for PCB analyses (splitless injection). Helium (He, 5.6 quality, Linde Gas, Toulouse, France) was used as carrier gas at a flow rate of $1 \mathrm{ml} \cdot \mathrm{min}^{-1}$ and nitrogen (N2, 5.0 quality, Linde Gas, Toulouse, France) was used as make up gas $\left(60 \mathrm{ml} . \mathrm{min}^{-1}\right)$. The injector temperature was $280^{\circ} \mathrm{C}$ and detector temperature was $320^{\circ} \mathrm{C}$. The temperature program was the following: $80^{\circ} \mathrm{C}$ for $2 \mathrm{~min}, 10^{\circ} \mathrm{C} \cdot \mathrm{min}^{-1}$ to $200^{\circ} \mathrm{C}, 200^{\circ} \mathrm{C}$ for $2 \mathrm{~min}$ and $2^{\circ} \mathrm{C} \cdot \mathrm{min}^{-1}$ to $320^{\circ} \mathrm{C}$ and $320^{\circ} \mathrm{C}$ for $20 \mathrm{~min}$. PCB and OCP compounds were quantified relative to internal standards. CBs 30, 103, 155 and 198 were used to quantify PCB whereas DDTd8 was used to quantify OCPs. The quantification was performed by means of a syringe standard using octachloronaphtalene to quantify internal standards to verify the recoveries for each sample. Quality control consisted of the analysis of procedural blanks, reproducibility and repeatability tests, injection of standard solutions as unknowns, and analysis of certified reference material SRM 2262 (NIST, USA) for PCBs. Details of procedures are given in Tapie et al. ${ }^{35}$. The lipid content was determined by gravimetric measurement from an aliquot of the extract.

Comparison with environmental contamination, assessed by sediment, water and wild oysters In the 2000s, investigations were conducted in order to estimate the chemical contamination of the urban and industrialized Adour estuary, especially by heavy metals, organometallic compounds (inorganic and methylmercury), PCBs and some other organochlorine compounds (DDTs). Work was performed especially on sediment ${ }^{31,36,37}$ and water $^{29,31,38}$ along the salinity mixing zone, as well as on wild oyster populations (Crassostrea gigas $)^{30}$ in the lower estuary up to the entrance of the urban zone. As no sampling was done in 
the two wetlands at that time, sediment and water were sampled in 2007 at these sites and analyzed for heavy metals according to procedures used during previous investigations ${ }^{29,36,37}$. Results from the water and sediment analyses are given as a tool for the interpretation of global tendencies underlined by the bioaccumulation in the eel organs, since the monitoring of these compartments (water, sediment) is not sufficient to guarantee the sound ecological state of the environment. Differences between sites were checked using non parametrical KruskallWallis tests and Mann-Whitney $U$ tests (Xlstat-Pro 7.5.2, Addinsoft, France).

\section{Results and discussion}

This paper is mainly focused on the description of heavy metals bioaccumulation in soft tissue of European eel from the Adour estuary, and on preliminary investigations on the contamination of eels by organochlorinated compounds. It is part of a multi-disciplinary approach initiated in 2003 by the IFREMER, the CNRS and the University of Pau to evaluate the impact of anthropogenic activities of the Adour basin and the Basque area on biota with eel as a biological model.

A total of 92 eels were sampled in the area of interest and analyzed for heavy metals $(N=92)$, mercury compounds $(N=22)$, PCBs and OCPs $(N=15)$. For this group, allometric measures gave a mean length of $35.2 \pm 10.7 \mathrm{~cm}$ and a mean weight of $106.4 \pm 117.8 \mathrm{~g}$. According to the Pearson coefficient, no correlation was found between elemental concentrations and length or weight whatever the organ and site. Eel tissue concentrations (mean, standard deviation and range) of heavy metals, total and methylmercury, PCBs and OCPs are presented in Table 1 and 2 for muscle. Results based on muscle, liver and gill analyses are illustrated in Figures 2, 3 and 4. As mercury levels (total and methylmercury) in eel muscle from the downstream estuary and SLG wetland were presented elsewhere ${ }^{33}$ they will not be discussed further in this work. Total mercury (Table 1) levels were thus only used to assess class quality according Belpaire and Goemans ${ }^{8}$ for this element.

\subsection{Levels and distribution of heavy metals in eel soft tissue}

\section{Tissue distribution}

All individuals carried significant heavy metal levels in liver and gill tissues, whereas concentrations of metals $\mathrm{Cd}, \mathrm{Ag}$ and $\mathrm{Pb}$ were not detected in some samples of muscle tissue. 
$\mathrm{Cu}$ and $\mathrm{Cd}$ are essentially stored in the liver (Fig. 2) where concentrations were up to 100 fold higher than in gills and muscle. As expected, $\mathrm{Zn}$ and $\mathrm{Pb}$ concentrations were also significantly higher in liver than in gills and muscle $(P<0.0001)$, but gills exhibited elevated concentrations compared to muscle. This distribution shown in previous studies ${ }^{39,40,41}$, could illustrate a joint exposure both by the direct (water) and trophic routes ${ }^{42}$. This result is also in concordance with other research carried out in eels and other fish species ${ }^{39,43,44,45}$ and could be explained by the induction of low-molecular weight proteins in the liver and gills, namely metallothionein (MT) that are involved in the sequestration of these elements ${ }^{46,47}$.

Bioconcentration of $\mathrm{Zn}$ within the gill tissue illustrates the role of gills as a first barrier regulating this element in eels from the Adour. According to the significant $\mathrm{Pb}$ levels found in sediments ${ }^{37}$ and the benthic behaviour of eels, the contribution of the skin in the metal uptake could be also suggested ${ }^{48}$.

Pierron et al. ${ }^{49}$ have recently highlighted the diet role in the uptake of $\mathrm{Cd}$ in eels from Gironde and Dordogne. Moreover, Cd was preferentially found in $\operatorname{liver}^{25}$ especially in the soluble fraction where it binds to MT, supporting our results. Ag was found preferentially in liver, although levels in muscle were higher than those found in gills. This latter distribution can be the consequence of the diet or fast transfer of the Ag element to the gastro intestinal tract and the other organs through the blood circulation as it was observed in rainbow trout Oncorhynchus mykiss ${ }^{50}$. Elemental concentrations of heavy metals $\mathrm{Cu}, \mathrm{Zn}, \mathrm{Cd}, \mathrm{Ag}$ and $\mathrm{Pb}$ in eel muscle from the Adour estuary were relatively low, averaging 268, 13998, 3.2, 47.6 and $10.8 \mathrm{ng} \mathrm{g}^{-1} \mathrm{ww}$ respectively. Such concentrations are well below those found by Maes et al. ${ }^{34}$ for the same species in Flanders. $\mathrm{Cd}, \mathrm{Pb}$ and $\mathrm{Zn}$ exposure found in the Adour was also less pronounced compared to the Loire estuary ${ }^{51}$. Moreover, concentrations were consistent with those described in other European aquatic systems with moderate chemical pressure such as the Cadiz Bay, River Turia and Piguena River in Spain ${ }^{43,45,52}$ and another French aquatic system, Camargues for the same species ${ }^{53}$. Finally, levels in sampled eels were in accordance with results obtained on macrobenthic organisms ${ }^{54}$ in this estuary supporting a moderate contamination.

\section{Spatial and temporal distribution}

According to the elemental distribution in soft tissues, geographical and temporal comparisons were made based on concentrations found in liver.

In order to evaluate the temporal variability in inorganic pressure, elemental concentrations measured in eel liver and gills from Termi site during the three sampling 
campaigns of 2006 (April, July and October) were compared. Termi was the only site where eels could be found at each sampling date, covering all 2006. Chemical pressure was significantly higher in July for $\mathrm{Pb}, \mathrm{Cu}, \mathrm{Cd}, \mathrm{Zn}$ and $\mathrm{Ag}(P<0.006)$ (Fig. 3). However, concentrations were not significantly different between October and April $(P>0.05)$. The increase of metal bioaccumulation in fish organs during the summer was observed in other environments ${ }^{44,55,56}$. Even if several factors could contribute to seasonal variability of metal accumulation in fish (physiological changes, variability of metal concentration in environment or diet), the authors highlight the strong relation between this metal increase and the period of rising temperature during the summer. Results of Köck et al. ${ }^{55}$ showed only a minor role of annual cycles of $\mathrm{pH}$ and metal concentration in the water and metal level of the diet in the seasonal pattern of metal concentration in liver and kidney of Arctic char (Salvelinus alpinus).

In our study water temperatures on Termi site were 10 to $16^{\circ} \mathrm{C}$ higher in summer than in Autumn and Spring coinciding with the higher metal loads found in both organs (liver, gills) during this period. Temperature is a major factor controlling the metabolism in poikilothermic organisms ${ }^{57}$ influencing the rate of metabolic processes especially the uptake, metabolism and excretion of metals ${ }^{58,59,60,61}$. The increase of water temperature leads also to an increase of gill ventilation rates in response to decreasing oxygen concentration in water ${ }^{57}$ resulting in a higher volume of water passing through the gills. The increase in metabolic rates during the summer could lead to an enhancement of the metal uptake from the water. Furthermore, the temperature also has a strong influence on the properties of the metal by changing the equilibrium effect between molecular and ionized forms. Prosi ${ }^{62}$ illustrated the example of $\mathrm{Cu}$ which in ionized forms is preferentially produced with higher temperature leading to a greater toxicity to the fish. Finally, results obtained on liver and gills of eels from Termi are consistent with an increase of the metal uptake linked to the seasonal temperature variability. The great variability of the estuary temperature (from 8 to $24^{\circ} \mathrm{C}^{63}$ ) may suggest a similar influence of this parameter on the pollutant levels found in eel tissues from the downstream site and have to be consider for further spatial comparisons.

Considering such an influence of the season, the spatial comparison was performed on the results obtained for each site in summer. Eels from the estuary exhibited significant higher levels of Ag than eels from each freshwater site (Mann Whitney, $P<0.05$ ) (Fig. 2). This can be explained by the input of a sewage treatment plant in the downstream estuary ${ }^{31,37}$ and the high affinity of $\mathrm{Ag}$ for organic compounds resulting in their accumulation in sediments receiving sewage. The $\mathrm{Zn}$ concentrations in liver were also significantly higher in the estuary (MannWhitney, $\mathrm{P}<0.05$; mean value: $\left.80.23 \pm 36.26 \mu \mathrm{g}_{\mathrm{g}} \mathrm{g}^{-1} \mathrm{ww}\right)$ than in the two wetlands sites 
(45.17 \pm 11.11 and $49.89 \pm 10.29 \mu \mathrm{g} . \mathrm{g}^{-1}$ respectively for SLG and Termi). This is in agreement with the reported bioaccumulation of both elements from three years monitoring using wild Pacific oysters (Crassostrea gigas) providing evidence of slightly higher pressure of $\mathrm{Zn}$ downstream in the estuary ${ }^{30}$. No significantly difference between the three sites was found for the $\mathrm{Cu}$ and $\mathrm{Pb}$ concentrations (Kruskal-Wallis, $\mathrm{P}=0.656$ and $\mathrm{P}=0.109$ respectively for $\mathrm{Cu}$ and $\mathrm{Pb})$

Conversely to $\mathrm{Ag}, \mathrm{Cu}$ and $\mathrm{Zn}, \mathrm{Cd}$ bioaccumulation was significantly different among sites $(\mathrm{P}<0.05)$. Results in the freshwater sites are five times higher $\left(282\right.$ to $2653 \mathrm{ng}^{\left.-\mathrm{g}^{-1} \mathrm{ww}\right)}$ than in the estuary (14 to $470 \mathrm{ng} \cdot \mathrm{g}^{-1} \mathrm{ww}$ ). The $\mathrm{Cd}$ concentrations were slightly higher in eels from SLG than on Termi site $(\mathrm{P}=0.039)$, probably because of its connection to the fluvial estuary zone which is impacted by $\mathrm{Cd}$ input from the gaves river $^{31}$. The existence of a significant decrease in $\mathrm{Cd}$ concentrations from the oligohaline zone to the polyhaline zone was observed for most of the benthic, pelagic and ichtyofauna compartments ${ }^{64,65,66}$. The speciation of $\mathrm{Cd}$ appears to be mostly controlled by marine inorganic ligands (Cl-). Concentrations of the suspended particulate matter (SPM) in the upstream part of the estuary decreases progressively against salinity in the 0 to $15 \%$ salinity $\operatorname{span}^{29}$. The $\mathrm{Cd}$ stock released from the SPM is then rapidly complexed by the inorganic anion ligands resulting in the formation of stable chlorocomplexes throughout the rest of the estuary ${ }^{67,68}$. Based on the benthic diet of eels and the Cd association to SPM in freshwater, diet might have a major role in such systems in Cd transfer to eels and explain the difference observed between estuary and upstream sites.

\section{Eel liver versus environmental element concentrations}

As in other studies, liver elemental concentrations observed in eels from the Adour basin (but also muscle) rarely reflect heavy metal exposure as assessed through the sediment and water average load for each site. Differences between fish tissue and environment levels probably reflect the major role of elemental bioavailability in the uptake, linked to both physical and chemical factors in the surrounding environment and physiological responses of the organisms ${ }^{69}$.

The observed discrepancy with the sediment load can be partly explained by the grain size variability within and across the studied sites as metals but also organic contaminants are often concentrated in fines particles due to their greater surface areas and amounts of organic carbon, clay, iron or aluminium ${ }^{70}$. In addition, the strong longitudinal gradients found in the Adour estuary for physicochemical parameters such as salinity, $\mathrm{pH}$, temperature, and ionic strength, are known to affect trace metal equilibrium, partitioning and reactivity ${ }^{71}$ resulting in 
significant modifications in the behaviour, bioavailability and phase transfer of metals in this estuary $^{29}$. Finally, fish have adaptive capacity under conditions of sublethal chronic metal given by physiological changes that result ultimately in acclimation with increased biosynthetic processes (mitosis, enhanced metal binding proteins synthesis such as metallothionein) and up-regulation of other pathways to counteract or compete with the deleterious effects of the metal (ion regulation) ${ }^{71}$. As a consequence, the apparent independence of $\mathrm{Zn}$ and $\mathrm{Cu}$ concentrations from the levels observed in the environment is not surprising, and, is in accordance with a previous study by Bruslé ${ }^{25}$.

\subsection{Lipid contents and organochlorinated compounds}

PCBs and OCPs were found in eels of the three sampling sites, but some OCP compounds were never or rarely found (Table 2).

\section{Lipid contents}

Lipid content in muscle was determined for 12 of the 15 eels used for organochlorinated compound analysis as not enough tissue was available to investigate lipid contents of all the individuals. Lipid contents represented overall $28 \pm 17 \%$ of the muscle weight, being $19 \pm 6 \%$ for estuarine eels $(N=5)$ and $34 \pm 20 \%$ for freshwater ones $(N=7)$. Several authors have discussed about the critical fat mass of yellow eels under which the energy reserves are thought not to be sufficient for the completion of the eel migration and successful reproduction ${ }^{72}$. According the values given by Van Der Thillart ${ }^{73}(2007 ; 20,7 \%)$ and Belpaire et al. ${ }^{72}(2009 ; 20 \%)$, eels from the downstream estuary have lipid contents close to the critical fat mass whereas eels from the freshwater have a fat mass above the threshold.

\section{Polychlorobyphenyles (PCBs)}

The sum of the 7 PCB congeners analyzed ( $(\mathrm{PCBs})$ ranged from 21 to $530 \mathrm{ng} \cdot \mathrm{g}^{-1} \mathrm{ww}$ in muscle with an overall average of $186.8 \pm 169.1 \mathrm{ng}^{-\mathrm{g}^{-1}}$ ww, i.e. 6 times less than concentrations measured in eels from Flanders Rivers $\left(605.0 \pm 1118.6 \mathrm{ng}^{-\mathrm{g}^{-1}} \mathrm{ww}^{34}\right)$. However, a pronounced difference in $\Sigma$ PCBs was observed between the freshwater sites and the downstream estuary, the latter $\left(370 \pm 99 \mathrm{ng}^{-\mathrm{g}^{-1}} \mathrm{ww}\right)$ exceeding almost by an order of magnitude those of the freshwater sites $\left(48 \pm 17\right.$ and $98 \pm 73 \mathrm{ng} \cdot \mathrm{g}^{-1} \mathrm{ww}$, respectively for Termi and SLG wetland). This trend was also found by expressing the $\sum$ PCBs on a lipid-weight basis. The $\sum$ PCBs from the Adour basin freshwater sites were moreover close to the results 
obtained in eels from some English Rivers ${ }^{74}$ but generally lower than most of the river basins studied by Maes et al. ${ }^{34}$ in Flanders and De Boer et al. ${ }^{75}$ in Netherlands. Conversely, values found in the downstream Adour estuary fall in the upper range detected by these latter authors. Within the muscle, among the various PCB congeners, CB153 and CB138 which are very recalcitrant compounds ${ }^{19}$ represent more than $50 \%$ of the total PCB concentrations for all sampling sites (Fig. 4).

Such a contribution was observed in previous studies ${ }^{7,34,52}$ and can be related to the physicochemical properties of these congeners, as they are apparently not metabolized by fish and easily transported bound to particles ${ }^{76}$. Despite the link between bioconcentration of PCBs in aquatic organisms and the degree of chlorination ${ }^{77}$, we found a significant contribution of low chlorinated compounds, 15\% for CB 28 and 37\% for CB 52 for example in liver. Furthermore, Figure 4 illustrates that the less chlorinated PCBs, such as 28 and 52, represent an abnormally low proportion of the $\sum$ PCBs in the downstream estuary compared to freshwaters sites. As less chlorinated PCBs do not show any significant difference between the two environments (see Table 2), dissimilar $\sum$ PCBs to $\sum$ CBs $(28,52)$ ratios come from higher levels in the heavier congeners, i.e. CB 101, 118, 153, 138 and 180 in the lower estuary. Such a trend could be explained by the lesser persistence of lighter congeners compared to heavier ones ${ }^{76}$, but this would involve a differential behaviour between the two environments separated geographically by only about $13 \mathrm{~km}$. This could also be linked to differences in the food web, diet available for eel within the freshwater and the saline water could have differently biomagnified heavier and lighter PCB congeners. Finally, the input from an intra-estuarine source enriched in heavier PCB congeners cannot be excluded. PCBs were analyzed in sediments, suspended particles (SPM) and wild oysters in the course of a three years survey in the Adour estuary. Gross flux would support that major PCB input originates from the watershed ${ }^{31}$, but oysters clearly recorded the input of additional sources of PCBs in the lower estuary area close to an industrial area $^{30}$. Industrial effluents heavily loaded with PCBs were identified ${ }^{31}$ in this area, some of them presenting high ratio $\sum$ PCBs to $\sum C B$ $(28,52)$ (Table 3). Ratios calculated in sediments and SPM show a similar trend as the ratio found in eel muscle with higher ratios in the low estuary compared to the upper estuary, although they never reach ratios as high as those found in eel muscle (Table 3). Even if little is known about the behaviour of PCB congeners across the estuarine salinity gradient, one would suggest that the observed trend in the $\sum \mathrm{PCBs} / \sum \mathrm{CB}(28,52)$ would be partly induced by sewage located in the industrial part of the lower estuary. 


\section{Organochlorine compounds}

Among the 11 OCPs investigated, three compounds were never found (Cis and Trans Chlordane, 2,4' DDD, 4,4' DDT) and two rarely found (Heptachlor, HCB). The sum of the OCPs detected in muscle was comprised of between 4 and $40 \mathrm{ng} \cdot \mathrm{g}^{-1} \mathrm{ww}$, with an overall average concentration of $21 \mathrm{ng} \cdot \mathrm{g}^{-1} \mathrm{Ww}$. Among the compounds analyzed, the composite 4,4' DDE had the highest contribution to the total OCPs in muscle with concentrations reaching $33.5 \mathrm{ng} \cdot \mathrm{g}^{-1}$ ww and an average concentration of $13.5 \pm 10.4 \mathrm{ng} \cdot \mathrm{g}^{-1}$ ww. Studies reporting p,p'DDE, suggest that the levels observed in the Adour are comparatively low compared to those observed in eels from Flanders rivers $\left(77.4 \pm 142.9\right.$ ng. $\mathrm{g}^{-1}$ ww muscle $\left.{ }^{34}\right)$ and in eels from English rivers (range values from 10 to $210 \mathrm{ng} . \mathrm{g}^{-1} \mathrm{ww}$ whole fish ${ }^{74}$ ). The sum of OCPs are found in slightly higher concentrations in the lower estuary $\left(29 \pm 9 \mathrm{ng} \cdot \mathrm{g}^{-1} \mathrm{Ww}\right)$ compared to the whole freshwater (12 $\pm 6 \mathrm{ng} \cdot \mathrm{g}^{-1} \mathrm{ww}$ and $23 \pm 18 \mathrm{ng} \cdot \mathrm{g}^{-1} \mathrm{ww}$, respectively for Termi and SLG), although high levels are sometimes found in the SLG wetland. Despite the decrease of dieldrin in aquatic systems during the last decade, Maes et al. ${ }^{34}$ illustrated the persistence of this pesticide which was banned in 1974 as it was found in more than $90 \%$ of eels analyzed in their study. In the small sampling group from the Adour 4,4' DDE was detected in all individuals.

Taking into account the three sites, lindane showed a maximum concentration of 2.14 ng. $\mathrm{g}^{-1} \mathrm{ww}$ and a minimum of $0.04 \mathrm{ng}^{-\mathrm{g}^{-1}} \mathrm{ww}$ in muscle illustrating a generally low contamination by the biocide compared to other systems like Flanders where levels were ten times higher $\left(27.9 \pm 131.68 \mathrm{ng} \cdot \mathrm{g}^{-1} \mathrm{ww}^{34}\right)$. Thirteen of the 16 eels analyzed for organochlorinated load showed HCB concentration below $1 \mathrm{ng} \cdot \mathrm{g}^{-1} \mathrm{ww}$.

\subsection{Quality class and human exposure}

In the context of the Water Framework Directive ${ }^{78}$ introduced by the European Community to protect aquatic life and human health, Maes et al. ${ }^{34}$ outlined the strong need to develop databases that serve as a baseline against which future policy results may be evaluated. These authors proposed eel as a suitable bioindicator species for monitoring a variety of priority substances in order to evaluate the chemical status of aquatic waters. Belpaire and Goemans ${ }^{8}$ built in that way a useful quality class framework based on an intensive eel muscle database for heavy metals, PCBs and OCPs in Flanders. This allows the determination of the chemical status of aquatic environments occupied by eel. As PCBs still remain problematic, they further proposed an action_value of $460 \mathrm{ng} . \mathrm{g}^{-1}$ ww and a target 
threshold value of $183 \mathrm{ng} \cdot \mathrm{g}^{-1}$ ww for $\sum$ PCBs giving a limit which should never be exceeded and the objective to attain these within planned time frames.

Boundary values of Belpaire and Goemans ${ }^{8}$ defined four quality classes representing clean or slightly polluted environments (Not deviating class), moderately polluted sites (Slightly deviating class), polluted sites (Deviating class) and finally highly polluted environments (Strongly deviating class). This classification was applied in the present study to individual eel muscle levels for total mercury, heavy metals (copper, zinc, cadmium and lead) and $\sum$ PCBs. The whole database was used in order to assess the global quality of the different sites at an annual scale. Results are shown in Table 4 and Figure 5.

A good chemical status of the overall freshwater sites was deduced from this approach whatever the contaminants (heavy metals or PCBs) and the sites, as $100 \%$ of individuals were assigned to either the not deviating or slightly deviating classes. This is however not the case for the downstream estuary, especially for mercury and $\sum$ PCBs, for which this site can be classified as significantly polluted with $100 \%$ of individuals classified as deviating or strongly deviating classes $\left(60 \%\right.$ of eels deviating for mercury and $82 \%$ eels deviating for $\left.\sum \mathrm{PCBs}\right)$. A large part of the total mercury burden was found to be methylmercury, the more toxic form of mercury, $86 \%$ of the samples from the estuary and $65 \%$ of those from the freshwater SLG ${ }^{33}$.

This phenomenon is not only explained by the high methylation potential of the sediments enhanced under anaerobic conditions in this estuary ${ }^{79}$ but also by the direct anthropogenic inputs of $\mathrm{MeHg}$ from specific discharge points ${ }^{36}$. Finally, in agreement with these results, the $\mathrm{MeHg}$ analysis in three different trophic groups (suspension feeders, predators and deposit feeders) from different sampling sites of the downstream Adour estuary showed that $\mathrm{MeHg}$ is also subject to biomagnification in the trophic food chain_in this ecosystem ${ }^{54}$. As suggested above, the high $\sum$ PCB load found in eel muscle of the downstream estuary would originate from the direct anthropogenic inputs in the restricted industrial area as well as probable biomagnification in the trophic food chain, as observed elsewhere ${ }^{8}$, eel being ultimately the more heavily PCB contaminated species.

Because most of the chemicals can pose great health risks to biota and humans, European and national legistlation have established a framework on admissible residue and contaminant levels in plant and animal feed that must not be exceeded.

For total mercury, concentrations in eel muscle of the Adour basin were always below, although close in the downstream estuary, to the $0.5 \mu \mathrm{g} \mathrm{Hg} \mathrm{g}^{-1}$ which is the maximum level set by the European Union for total $\mathrm{Hg}$ in foodstuffs ${ }^{80}$ and the accepted value set by the World Health Organisation for human consumption (International Program on Chemical Safety, Environmental Health Criteria No. 1, Mercury). For $\mathrm{Zn}, \mathrm{Cu}, \mathrm{Cd}$ and $\mathrm{Pb}$ average 
concentrations were also significantly below the European norms of consumption as well as the recommended values given by Ricoux and Gasztwott ${ }^{81}$ (Table 1), Canada $(\mathrm{Cu}: 100000$ ng.g ${ }^{-1}$ ww ; Zn: 100000 ng.g ${ }^{-1}$ ww), Hungary (Cu: 60000 ng.g ${ }^{-1}$ ww; Zn : 80000 ng.g ${ }^{-1}$ ww) and Australia (Cu: $\left.60 \mu \mathrm{g} \cdot \mathrm{g}^{-1} \mathrm{ww} ; \mathrm{Zn}: 150 \mu \mathrm{g} \cdot \mathrm{g}^{-1} \mathrm{ww}\right)^{7}$.

The directive 1996/33/CE ${ }^{82}$ given by the European Union sets a maximum content of 200 ng.g ${ }^{-1}$ PCBs lipid basis, calculated as the sum of the 7 "target" congeners (PCB 28, 52, $101,118,138,153,180)$ in meat, poultry and derived product. However, no recommendation was published for fish. Our results expressed on lipid basis for the three sites ranged from $193 \pm 59 \mathrm{ng} . \mathrm{g}^{-1}$ for the Termi site to $1321 \pm 352 \mathrm{ng}^{-\mathrm{g}^{-1}}$ for the estuary with an intermediate level for SLG $\left(348 \pm 260 \mathrm{ng} \cdot \mathrm{g}^{-1}\right)$. Data were close to or above the threshold established for food especially in the downstream estuary. Additionally, the European Commission established in $2006^{80}$ a maximum level for the sum of dioxins, furans and dioxin-like PCBs (12 ngWHOPCDD/F-PCB-TEQ $\mathrm{kg}^{-1}$ ) in the muscle meat of eel. Although the most toxic dioxin-like PCBs, dioxins and furans were not monitored in our study, we used the empirical relationship between the concentrations of the PCB congener 153 in ng. ${ }^{-1}$ ww and the ng PCB TEQ $\mathrm{kg}^{-1}$ fresh weight demonstrated by De Boer et al. ${ }^{83}$ to evaluate the risk of eel consumption in the Adour estuary. With an average concentration of 163 ng. ${ }^{-1}$ ww, the PCB congener 153 corresponds to $12.7 \mathrm{ng}$ PCB TEQ kg${ }^{-1}$ ww in the muscle of eel from the lower estuary. As this calculation does not take into account the presence of dioxins and furans, it can be stated that muscle meat exceeded the maximum admissible value.

As for PCB, no maximum residue limit (MRL) has yet been provided for DDT and its metabolites in fish. However, the European Union fixed a tolerance limit of $1000 \mathrm{ng}^{-\mathrm{g}^{-1} \mathrm{ww}}$ on lipid basis for some food products of animal origin such as milk, meat or eggs, based on the sum of p,p'-DDT, p,p'DDE, p,p'-DDD and o,p'-DDD ${ }^{82}$. These data were calculated for our samples and were below the given limit $\left(46 \pm 22 \mathrm{ng} . \mathrm{g}^{-1}\right.$ on lipid basis, $80 \pm 60 \mathrm{ng} \cdot \mathrm{g}^{-1}$ on lipid basis, $105 \pm 33$ ng. $\mathrm{g}^{-1}$ on lipid basis for Termi, SLG and estuary sampling sites, respectively) supporting the moderate contaminated characteristic of the area under focus for OCP contaminants.

\section{Conclusion}

Data presented in this study are in good agreement with other European aquatic environments under moderate chemical pressure both in terms of environment characterisation and eel quality, especially for contaminants such as heavy metals and organochlorine compounds. The occasional consumption of eels caught in the basin does not 
seem to present a risk for human for these contaminants. However, care must be taken with eels from the downstream estuary which exhibit high $\mathrm{MeHg}$ and PCB loads that could represent a potential risk for top predators such as birds and perhaps humans. Even if eel contamination supports other European temporal studies showing a decrease in levels of organochlorinated compounds, it illustrated their persistence in organisms, especially in eels where they are concentrated to a large extent ${ }^{8}$ compared to other aquatic organisms due to the species trophic status (carnivorous). Despite a seasonal influence on heavy metal loads in eel from the freshwater sites and a lack of samples to investigate such an influence in the estuary, the great persistence of PCBs in the environment and the biomagnification abilities of mercury in aquatic organisms still highlight the potential threat of these contaminants at the eel life scale and on eel consumers. Further investigations will be necessary to better identify the extent of the zone contaminated by mercury and PCBs. Knowing that $75 \%$ of stored lipids in eels could be remobilized during the trans-oceanic migration ${ }^{84}$, and $18 \%$ directly allocated to gonad development, and given the complexity of natural environment (geochemical cycles, interaction between pollutants), studies are still needed to evaluate if the sublethal concentrations observed are worrying or not for the complete fulfilment of the biological cycle of this declining species.

\section{ACKNOWLEDGEMENTS}

This work was supported by the European Community (IFOP), the IFREMER and the CNRS. The authors are grateful to the National Water and Aquatic Environment Office (ONEMA) and MIGRADOUR for their help in the field logistics and fish sampling. We also thank Rosy Cox, a native English speaker, for providing writing assistance that lead to the clarity and fluency of the English language. Hélène Tabouret acknowledges IFREMER and the Aquitaine Region for her doctoral fellowship. Aquitaine Région is also thanked for financial support and more especially for their help in equipment purchase.

\section{References}

1 - Philipps, D.J.H., 1977. The use of biological indicator organisms to monitor trace metal pollution in marine and estuarine environments - a review. Environ. Pollut. 13, 281-317.

2 - Van der Oost, R., Vindimian, E., Van Den Brink, P.J., Satumalay, K., Heida, H.,Vermeulen, N.P.E., 1997. Biomonitoring aquatic pollution with feral eel (Anguilla anguilla). III. Statistical analyses of relationships between contaminant exposure and biomarkers. Aquat. Toxicol. 39, 45-75.

3 - Rainbow, P.S., 2006. Biomonitoring of trace metals in estuarine and marine environments. Aust. J. Ecotox. $12,107-122$.

4 - Feunteun E., 2002. Management and restoration of European eel population (Anguilla anguilla): An impossible bargain. Ecol. Eng. 18, 575-591.

5 - Belpaire, C., Goemans, G., 2007a. Eels: contaminant cocktails pinpointing environmental contamination. ICES J. Mar. Sci. 64, 1423-1436.

6 - Maes, G.E., Raeymaekers, J.A.M., Pampoulie, C., Seynaeve, A., Goemans, G., Belpaire, C., Volckaert, F.A.M., 2005. The Catadromous European Eel Anguilla Anguilla (L.) as a Model for Freshwater 
Evolutionary Ecotoxicology: Relationship between Heavy Metal Bioaccumulation, Condition and Genetic Variability. Aquat. Toxicol. 73, 99-114.

7 - Storelli, M.M., Barone, G., Garofalo, R., Marcotrigiano, G.O., 2007. Metals and organochlorine compounds in eel (Anguilla anguilla) from the Lesina lagoon, Adriatic Sea (Italy). Food Chem. 100, 1337-1341.

8 - Belpaire, C., Goemans, G., 2007b. The European eel Anguilla anguilla, a rapporteur of the chemical status for the Water Framework Directive? Vie Milieu 57(4), 235-252.

9 - WG Eel. 2006. FAO European Inland Fisheries Advisory Commission, and the International Council for the Exploration of the Sea. Report of the 2006 session of the Joint EIFAC/ICES Working Group on Eels, Rome, 23-27 January 2006. EIFAC Occasional Paper. 38. ICES Document CM 2006/ACFM: 16. 352 pp.

10 - STECF. 2006. Scientific, Technical and Economic Committee for Fisheries of the Commission of the European Communities. 22nd Report of STECF, Draft Version 27, April 2006.

11 - Moriarty, C., 1999. Strategy for the development of the eel fishery in Ireland. Irish Fish. Bull. 19, 1-47.

12 - Daverat, F., Tomas, J., 2006. Tactics and demographic attributes in the European eel Anguilla anguilla in the Gironde watershed, SW France. Mar. Ecol.- Prog. Ser. 307, 247-257.

13 - Tesch, F.W., 1977. The Eel Biology and Management of Anguillids Eels. Translated by Jennifer Greenwood. English Edition, Greenwood, P. H., Chapman D. Se., and Hall Ltd (Eds.). Londres, 423p.

14 - Van der Oost, R., Van Shooten, F.J., Ariese, F., Heida, H., Vermeulen, N.P.E., 1994. Bioaccumulation, biotransformation and DNA binding of PAHs in feral eel (Anguilla anguilla) exposed to polluted sediments: a field survey. Environ. Toxicol. Chem. 13, 859-870.

15 - Roche, H., Buet, A., Ramade, F., 2002. Relationships between persistent organic chemicals residues and biochemical constituents in fish from a protected area: the French National Nature Reserve of Camargue. Comp. Biochem. Phys. C 133, 393-410.

16 - Feunteun E., Laffaille P., Robinet T., Briand C., Baisez A., Olivier J.-M , Acou, A., 2003. A review of upstream migration and movements in inland waters by anguillid eels: toward a general theory, in : Aida K., Tsukamoto K., Yamauchi K., Eds. Advances in eel biology. Tokyo, Springer - Verlag, pp. 191-213.

17 - Tabouret, H., Bareille, G., Claverie, F., Pécheyran, C., Prouzet, P., Donard, O.F.X., 2010. Simultaneous use of strontium:calcium and barium:Calcium ratios in otoliths as markers of habitat: Application to the European eel (Anguilla anguilla) in the Adour basin, South West France. Marine Environmental Research, 70(1), 35-45.

18 - Larsson, P., Hamrin, S., Okla, L., 1991. Factors determining the uptake of persistant pollutants in an eel population (Anguilla anguilla L.). Environ. Poll. 69, 39-50.

19 - Knights, B., 1997. Risk assessment and management of contamination of eels (Anguilla spp.) by persistent xenobiotic organochlorine compounds. Chem. Ecol. 13, 171-212.

20 - Harrad, S., Smith, D., 1999. Eel consumption as a pathway of human exposure to PCBs. Int. J. Environ. Health Res. 9, 31-37.

21 - Moriarty C., Dekker W., (Eds) 1997. Management of European eel fisheries. Irish Fish. Bull. 15, 108p.

22 - European Commission, 1998. Statement from the European eel industry farmers, traders, processors and institutions meeting with the European Commission DG XIV Brussels 27 October 1998, 11 p.

23 - ICES, 2007. Report of the 2007 Session of the Joint EIFAC/ICES Working Group on Eels (WGEEL), Bordeaux (France), 3-7 September 2007. ICES CM 2007/ACFM:23; EIFAC Occasional Paper No. 39. ICES Advisory Committee on Ecosystems, pp 163

24 - ICES, 2008. Report of the 2008 session of the Joint EIFAC/ICES Working Group on Eels (WGEEL), Leuven (Belgium), 3-9 September 2008. ICES CM 2008/ACOME:15; EIFAC Occasional Paper No. 43. ICES Advisory Committee on Ecosystems, pp 352

25 - Bruslé, J., 1990. Effects of heavy metals on eels, Anguilla sp. Aquat. Living Res. 3, 131-141.

26 - Robinet, T., and Feunteun, E., 2002. Sublethal Effects of Exopsure to Chemical Compounds: A cause for the Decline in Atlantic Eels? Ecotoxicology 11, 265-277.

27 - Geeraerts, C., Belpaire, C., 2010. The effects of contaminants in European eel: a review. Ecotoxicology 19, 239-266.

28 - Morandeau, G., Casamajor (De), M.-N., Caill-Milly, N., 2009. Pêche maritime dans le bassin de l'Adour et les courants côtiers landais en 2007 (saison civelle 2007/2008). Rapport Ifremer, 41p.

29 - Point, D., 2004. Spéciation et Biogéochimie des éléments traces métalliques dans l'estuaire de l'Adour. Ph.D. Thesis, Université de Pau et des Pays de l'Adour, pp. 218.

30 - Trut, G., Mayeur, D., 2004. Etude de la qualité des eaux de l'estuaire de l'Adour (suivi 2001-2003). Ifremer, 100 .

31 - Bareille, G., Amouroux, D., Lespes, G., Potin-Gautier, M., Donard, O.F.X., 2005. Rivières pyrénéennes du piémont atlantique : de l'érosion des sols à la pollution chimique et microbienne : caractérisation de la contamination et du fonctionnement de l'estuaire de l'Adour. ECOBAG Programme de recherche Cahier technique ${ }^{\circ} 1 / 4$ - Agence de l'Eau Adour-Garonne, pp.11-18.

32 - Prouzet, P. [Coord.], 2002. Historique des captures de civelles, intensité de leur exploitation, variation de leur capturabilité par la pêche professionnelle maritime et indices de colonisation sur le bassin versant de l'Adour. Contrat EC/DG FISH (DGXIV) 99/023, 147p. 
33 - Arleny, I., Tabouret, H., Rodriguez-Gonzales, P., Bareille, G., Donard, O. F. X., Amouroux, D., 2007. Methylmercury bioconcentration in muscle tissue of the European eel (Anguilla anguilla) from the Adour estuary (Bay of Biscay, France). Mar. Poll. Bull. 54(7), 1031-1036.

34 - Maes, G.E., Belpaire, C., Goemans, G., 2008. Spatial variations and temporal trends between 1994 and 2005 in polychlorinated biphényls, organochlorine pesticides and heavy metals in European eel (Anguilla anguilla L.) in Flanders, Belgium. Environ. Pollut. 153(1), 223-237.

35 - Tapie N., Budzinski H., Le Menach K., 2008. Fast and efficient extraction methods for the analysis of polychlorinated biphenyls and polybrominated diphenyl ethers in biological matrices. Anal. Bioanal. Chem., 2008, 391, 2169-2177.

36 - Stoichev, T., Amouroux, D., Wasserman, D., Point, D., De Diego, G., Bareille, G., Donard, O.F.X., 2004. Dynamics of mercury species in surface sediments of the macrotidal estuarine - coastal system (Adour river, Bay of Biscay). Estuar. Coast. Shelf S. 59, 511-521.

37 - Bareille, G., Point, D., Amouroux, D., Monperrus, M., Etcheber, H., Donard, O.F.X., 2006. Geochemistry of trace metals of bed and suspended sediments from the urban Adour estuary. International Symposium on Oceanography of the Bay of Biscay, April 19-21 2006, Vigo-Spain 1-4.

38 - Point, D., Bareille, G., Amouroux, D., Etcheber, H., Donard, O.F.X., 2007. Reactivity, interactions and transport of trace elements, organic carbon and particulate material in a mountain range river system (Adour River, France). J. Environ. Monitor. 9(2), 157-167.

39 - Oliveira Ribeiro, C. A., Vollaire, Y., Sanchez-Chardi, A., Roche, H., 2005. Bioaccumulation and the effects of organochlorine pesticides, PAH and heavy metals in the Eel (Anguilla anguilla) at the Camargue Nature Reserve, France. Aquat. Toxicol. 74(1): 53-69.

40 - Sun, L. T., Jeng, S.S., 1998. Comparative zinc concentrations in tissues of common carp and other aquatic organisms. Zool. Stud. 37(3), 184-190.

41 - Yilmaz, F., Ozdemir, N., Demirak, A., Levent Tuna, A., 2007. Heavy metal levels in two fish species Leuciscus cephalus and Lepomis gibbosus. Food Chem. 100(2), 830-835.

42 - Pedlar, R.M., and Klaverkamp, J.F., 2002. Accumulation and distribution of dietary arsenic in Lake Whitefish (Coregonus clupeaformis). Aquat. Toxicol. 57(3), 153-66.

43 - Linde, A.R., Sánchez-Galán, S., Klein, D., Garcia-Vázquez, E., Summer, K.H., 1999. Metallothionein and Heavy Metals in Brown Trout (Salmo trutta) and European Eel (Anguilla anguilla): A Comparative Study. Ecotox. Environ. Safe 44, 168-173.

44 - Avenant-Oldewage, A., Marx, H.M., 2000. Bioaccumulation of chromium, copper and iron in the organs and tissues of Clarias gariepinus in the Olifants River, Kruger National Park. Water SA 26(4), 569-582.

45 - Usero J., Izquierdo C., Morillo J., Gracia I., 2003. Heavy metals in fish (Solea vulgaris, Anguilla anguilla, Liza aurata) from salt marshes on the southern Atlantic coast of Spain. Environ. Int. 29, 949-956.

46 - Langston, W. J., Chesman, B. S., Burt, G. R., Pope, N. D., McEvoy, J., 2002. Metallothionein in liver of eels Anguilla anguilla from the Thames Estuary: An indicator of environmental quality? Mar. Env. Res. 53, 263-293.

47 - Wepener, V., Van Vuren, J.H.J., Du Preez, H.H., 2001. Uptake and distribution of a copper, iron, and zinc mixture in gill, liver and plasma of a freshwater teleost, Tilapia sparrmanii. Water S.A. 27(1), 99-108.

48 - Ahmed, M.S., Bibi, S., 2010. Uptake and Bioaccumulation of waterborne lead $(\mathrm{Pb})$ in the fingerlings of a freshwater cyprinid, Catla catla L. J. Anim. Plant Sci. 20(3), 201-207.

49 - Pierron, F., Baudrimont, M., Lucia, M., Durrieu, G., Massabuau, J.-C., Elie, P., 2008. Cadmium uptake by the European eel: Trophic transfer in field and experimental investigations. Ecotox. Environ. Safe. 70(1), 10-19.

50 - Galvez, F., Mayer, G. D., Wood, C.M., Hogstrand, C., 2002. The distribution kinetics of waterborne silver$110 \mathrm{~m}$ in juvenile rainbow trout. Comp. Biochem. Phys. C 131(3), 367-378.

51 - Amiard, J.C., Amiard-Triquet, C., Metayer, C., 1982. Distribution de quelques métaux (Cd, $\mathrm{Pb}, \mathrm{Cu}, \mathrm{Zn})$ chez les organismes vivants de l'estuaire de la Loire et des zones côtières adjacentes. Bull. Soc. Sci. Nat. Ouest Fr. 4, 153-168.

52 - Bordajandi, L.R., Gómez, G., Fernández, M.A., Abad, E., Rivera, J., González, M.J., 2003. Study on PCBs, PCDD/Fs, organochlorine pesticides, heavy metals and arsenic content in freshwater fish species from the River Turia (Spain). Chemosphere 53: 163-171.

53 - Batty, J., Pain, D., Caurant, F., 1996. Metal Concentrations in Eels Anguilla anguilla from the Camargue Region of France. Biol. Conserv. 76, 17-23.

54 - Monperrus, M., Point, D., Grall, J., Chauvaud, L., Amouroux, D., Bareille, G., Donard O., 2005. Determination of metal and organometal trophic bioaccumulation in the benthic macrofauna of the Adour estuary coastal zone (SW France, Bay of Biscay). J. Environ. Monitor. 7, 1-9.

55 - Köck, G., Triendl, M., Hofer, R., 1995. Seasonal patterns of metal accumulation in Arctic char (Salvelinus alpines) from an oligotrophic Alpine lake related to temperature. Can. J. Fish. Aquat. Sci. 53, 780-786.

56 - Farkas, A., Salánki, J., Varanka, I., 2008. Heavy metal concentrations in fish of Lake Balaton. Lakes Reservoirs: Res. Manage. 5(4), 271-279.

57 - Bennett, A. F., 1978. Activity metabolism of the lower invertebrates. Annu. Rev. Physiol. 400, 447-469. 
58 - Cairns, J., Health, A.G., Parker, B.C. 1975. Temperature influence on chemical toxicity to aquatic organisms. J. Water Poll. Cont. Fed. 47, 267-280.

59 - Robinson, W.R., Peters, R.H., Zimmerman, J., 1983. The effects of body size and temperature on metabolic rate of organisms. Can.J. Zool. 61, 281-288.

60 - Leaner, J.J., Mason, R.P., 2002. Methylmercury accumulation and fluxes across the intestine of channel catfish, Ictalurus punctatus. Comp. Biochem. Phys. C 132(2), 247-259.

61 - Tsui, M.T.K., Wang, W.-X., 2004. Temperature influences on the accumulation and elimination of mercury in a freshwater cladoceran, Daphnia magna. Aquat. Toxicol. 70(3), 245-256.

62 - Prosi, F., 1979. Heavy metals in aquatic organisms, in: Förstner, U. and Wittmann, G.T.W. (Eds.), Metal Pollution in the Aquatic Environment. Springer-Verlag, Berlin, pp.271-323.

63 - Augris C., Caill-Milly N., de Casamajor M.-N. (coord.), 2009. Atlas thématique de l'environnement marin du Pays basque et du sud des Landes. 128 p. Édition Quae-Ifremer.

64 - Gonzalez, J.-L., (Coord.) 1999. Le Cadmium : comportement d'un contaminant métallique en estuaire. Programme Scientifique Seine Aval, fascicule 10. Editions IFREMER, $31 \mathrm{pp}$.

65 - Culshaw, C., Newton, L.C., Weis, I., Bird, D.J., 2002. Concentrations of Cd, Zn and Cu in sediments and brown shrimps (Crangon crangon L.) from the Severn estuary and Bristol Channel, UK. Mar. Environ. Res. 54, 331-334.

66 - Dauvin, J.-C, 2008. Effects of heavy metal contamination on the macrobenthic fauna in estuaries: The case of the Seine estuary. Mar. Poll. Bull. 57, 160-169.

67 - Kraepiel, A. M. L, Chiffoleau, J.F., Martin, J.-M., Morel, F. M. M., 1997. Geochemistry of trace metals in the Gironde estuary. Geochim. Cosmochim. Ac. 61(7), $1421-1436$.

68 - Garnier, J.M., Gieu, C., 2003. Release of cadmium in the Danube estuary: contribution of physical and chemical processes as determined by an experimental approach. Mar. Env. Res. 55, 5-25.

69 - Zhang, L., Wang, W.-X., 2007. Waterborne cadmium and zinc uptake in a euryhaline teleost Acanthopagrus schlegeli acclimated to different salinities. Aquat. Toxicol. 84(2), 173-181.

70 - Santschi, P.H., Presley, B.J., Wade, T.L., Garcia-Romero, B., Baskaran, M., 2001. Historical contamination of PAHs, PCBs, DDTs, and heavy metals in Mississipi River delta, Galveston bay and Tampa bay sediments. Mar. Env. Res. 52, 51-79.

71 - Millward, G.E,. Turner, A., 1995. Trace elements in estuaries, in: Salbu, B., and Steinnes, E. (Eds.), Trace Metals in natural waters. CRC Press, Boca Raton., pp. 223-245.

72 - Belpaire, C.G.J., Goemans, G., Geeraerts, C., Quataert, P., Parmentier, K., Hagel, P., De Boer, J., 2009. Decreasing eel stocks : survival of the fattest ? Ecol. Freshwat. Fish 18, 197-214.

73 - Van den Thillart, G.E.E.J.M., Palstra, A.P. \& van Ginneken, V.J.T. 2007. Simulated migration of European silver eel: swim capacity and cost of transport. J. Mar. Sci. Technol. 15 (special issue), 1-16.

74 - Mason, C.P., 1993. Organochlorine pesticide residues and PCBs in eels Anguilla anguilla from the British reedbeds. Chemosphere 26, 2289-2292.

75 - De Boer, J., Dao, Q.T., Van Leeuwen, S.P.J., Kotterman, M.J.J., Schobben, J.H.M., 2010. Thirty year monitoring of PCBs, organochlorine pesticides and tetrabromodiphenylether in eel from the Netherlands. Environ. Poll. 15, 1228-1236.

76 - Szlinder-Richert J, Barska I, Mazerski J, Usydus Z, 2009. PCBs in fish from the southern Baltic Sea: levels, bioaccumulation features, and temporal trends during the period from 1997 to 2006. Mar. Poll. Bull. 58, 85-92.

77 - Fox, K., Zauke, Gerd, P., Butte, W., 1994. Kinetics of bioconcentration and clearance of 28 polychlorinated biphenyls congeners in zebrafish (Brachydanio rerio). Ecotox. Environ. Safe. 28, 99-109.

78 - European Commission, 2006 (a). Proposal for a Directive of the European Parliament and of the Council on Environmental Quality Standards in the Field of Water Policy and Amending Directive 2000/60/EC (presented by the Commission) $\{\mathrm{COM}(2006) 398$ final $\}$ SEC(2006) 947\}. Commission of the European Communities, Brussels. 17.7.2006 COM(2006) 397 final 2006/0129 (COD).

79 - Rodriguez Martin-Doimeadios, R.C., Tessier, E., Amouroux, D., Guyoneaud, R., Duran, R., Caumette P., Donard, O.F.X., 2004. Mercury methylation/demethylation and volatilization pathways in estuarine sediment slurries using species-specific enriched stable isotopes. Mar. Chem. 90, 107-123.

80 - European Commission, 2006 (b). Commission Regulation (EC) No. 199/2006 of 3 February 2006 amending Regulation (EC) No. 466/2001 setting maximum levels for certain contaminants in foodstuffs as regards dioxins and dioxin-like PCBs. Official Journal of the European Union L32, 34-46.

81 - Ricoux, C., Gasztwott, B., 2005. Evaluation des risques sanitaires liés à l'exposition de forts consommateurs de produits de la pêche de rivière contaminés par des toxiques de l'environnement. Rapport du CIRE, p72.

82 - European Commission, 1996. Council directive 96/33/EC of 21 May 1996 amending the Annexes to Directives 86/362/EEC and 86/363/EEC on the fixing of maximum levels for pesticide residues in and on cereals and foodstuffs of animal origin respectively. Official Journal of the European Communities 18.06.1996. 
83 - De Boer, J., Stronck, J., Traag, W.A., Van der Meer, J., 1993. Non-ortho and mono-ortho substituted chlorobiphenyls and clorinated dibenzo-p-dioxins and dibenzofurans in marine and freshwater fish and shellfish from the Netherlands. Chemosphere 26, 1823-1842.

84 - Boëtius, I., Boëtius, J., 1980. Experimental maturation of female silver eels, Anguilla anguilla, estimates of fecundity and energy reserves for migration and spawning. Dana 1, 1-28. 
Table 1. Mean heavy metal concentrations. standard deviation (Std. Dev.) and range (in $n g^{1}$ wet weight) in yellow eel muscle from the Adour estuary and two associated watersheds(Termi. St Laurent de Gosse SLG). Norm s and recom mended lim its (recom. limits) are given

\begin{tabular}{|c|c|c|c|c|c|c|c|c|c|c|c|c|c|}
\hline & \multicolumn{4}{|c|}{ Termi } & \multicolumn{4}{|c|}{ StLaurent de Gosse } & \multicolumn{4}{|c|}{ Downstream estuary } & $\begin{array}{l}\text { Norms or } \\
\text { recom } \\
\text { limits }\end{array}$ \\
\hline \multicolumn{14}{|l|}{ Heany metals } \\
\hline \multirow[t]{2}{*}{$\mathrm{N}$} & \multicolumn{4}{|c|}{51} & \multicolumn{4}{|c|}{21} & \multicolumn{4}{|c|}{20} & \\
\hline & mean & Std Dev: & $\max$ & $\min$ & mean & Std. Dev: & $\max$ & $\min$ & mean & Std Dev: & $\max$ & $\min$ & \\
\hline Age (year) & 8 & 2 & 11 & 4 & 7 & 2 & 10 & 5 & 7 & 1 & 9 & 4 & \\
\hline Length $(\mathrm{cm})$ & 31.8 & 5.7 & 49.0 & 21.4 & 35.6 & 13.6 & 63.0 & 19.6 & 43 & 11 & 60 & 24 & \\
\hline Weight (g) & 70.4 & 55.7 & 320.0 & 15.0 & 112.9 & 140.2 & 502.0 & 12.0 & 153 & 132 & 518 & 26 & \\
\hline $\mathrm{Cu}$ & 263 & 147 & 664 & 7 & 359 & 156 & 695 & 100 & 198 & 59 & 351 & 110 & $\left.10000^{2}\right)$ \\
\hline $\mathrm{Zn}$ & 14279 & 6743 & 42175 & 648 & 15145 & $5 s s 2$ & 29510 & 6192 & 12567 & 3445 & 21194 & 6537 & $\left.35000^{2}\right)$ \\
\hline Ag & 40 & 46 & 136 & $<\mathrm{LD}$ & 26 & $2 s$ & 75 & 1 & 1 & 4 & 17 & 1 & \\
\hline Cd & 4 & 3 & 14 & $<\mathrm{LD}$ & 4 & 2 & 7 & $<\mathrm{LD}$ & 1 & 1 & 5 & $<\mathrm{LD}$ & $100^{1)}$ \\
\hline $\mathrm{Pb}$ & 10 & 9 & 49 & 1 & 14 & 10 & 52 & 7 & 4 & 5 & 17 & $<\mathrm{LD}$ & $500^{1)}$ \\
\hline Total $\mathrm{Hg}$ & - & - & - & - & 179 & 119 & 236 & 43 & 307 & 158 & 476 & 95 & $500^{1)}$ \\
\hline $\mathrm{MeHg}$ & - & - & - & - & 155 & 80 & 110 & 31 & 449 & 125 & 265 & 92 & \\
\hline
\end{tabular}

1) European Comm ission. 2006b

2) Ricoux. C.. Gasztwott B. 2005 
Table 2. Mean organochlorine compounds concentrations, standard deviation (Std. Dev.) and range (in $n g g^{1} w w$ ) in yellow eel muscle from the Adour estuary and two associated watershed(Termi St Laurent de Gosse SLG)

\begin{tabular}{|c|c|c|c|c|c|c|c|c|c|c|c|c|}
\hline \multirow{3}{*}{$\bar{N}$} & \multicolumn{4}{|c|}{ Termi } & \multicolumn{4}{|c|}{ StLaurent de Gosse } & \multicolumn{4}{|c|}{ Downstream estuary } \\
\hline & \multicolumn{2}{|c|}{7} & \multirow[b]{2}{*}{$\max$} & \multirow[b]{2}{*}{$\min$} & \multicolumn{2}{|c|}{3} & \multirow{2}{*}{\multicolumn{2}{|c|}{$\min$}} & \multicolumn{2}{|c|}{6} & \multirow[b]{2}{*}{$\max$} & \multirow[b]{2}{*}{$\min$} \\
\hline & mean & Std.Dev: & & & mean & Std Dev: & & & mean & Std.Dev: & & \\
\hline Age (year) & 8 & 1 & 10 & 6 & 8 & 2 & 10 & 7 & 7 & 2 & 9 & 5 \\
\hline Length (cm) & 33.2 & 2.0 & 35.6 & 30.3 & 47.9 & 12.9 & 59.0 & 33.8 & 41.2 & 10.3 & 57.0 & 30.0 \\
\hline Weight (g) & 81.8 & 22.2 & 108.0 & 54.0 & 260.3 & 222.5 & 502.0 & 64.0 & 114.1 & 53.4 & 183.6 & 37.0 \\
\hline CB 28 & 3.86 & 1.57 & 6.18 & 0.56 & 5.66 & 2.03 & 7.46 & 3.46 & 5.05 & 1.29 & 6.93 & 2.97 \\
\hline CB 52 & 7.72 & 4.51 & 14.90 & 2.46 & 12.52 & 9.23 & 21.63 & 3.17 & 9.11 & 2.56 & 12.94 & 5.91 \\
\hline CB 101 & 3.04 & $1.2 S$ & 4.30 & 0.68 & 3.67 & 3.41 & 7.42 & 0.73 & 9.38 & 5.57 & 19.95 & 5.24 \\
\hline CB 118 & 7.17 & 3.15 & 11.72 & 2.01 & 10.32 & 11.26 & 22.97 & 1.39 & 36.34 & 9.81 & 48.64 & 19.63 \\
\hline CB 153 & 14.70 & 4.45 & 19.20 & 8.20 & 32.71 & 25.51 & 60.95 & 11.32 & 162.78 & 41.24 & 230.88 & 108.78 \\
\hline CB 138 & 7.62 & 2.47 & 10.90 & 4.26 & 22.44 & 20.26 & 45.14 & 6.20 & 94.46 & 26.65 & 139.01 & 63.38 \\
\hline CB 180 & 4.33 & 3.31 & 10.40 & 0.97 & 10.23 & $5.4 S$ & 19.97 & 4.54 & 52.67 & 15.37 & 82.10 & 31.79 \\
\hline$\Sigma$ TOT PCB & 48.43 & 16.52 & 64.33 & 20.54 & 97.54 & 72.54 & 175.26 & 30.82 & 369.79 & 95.55 & 530.07 & 238.49 \\
\hline $\bar{\Sigma}$ TOT PCB on lipid basis* & 192.89 & 58.98 & 229.7 & 73.4 & 348.4 & 260.2 & 625.9 & 110.1 & 1320.7 & 352.0 & 1893.1 & 851.74 \\
\hline CB-TEQ (ng kg-1) & 1.712 & 0.329 & 2.04 & 1.23 & 3.04 & 1.59 & 5.13 & 1.46 & 12.67 & 3.05 & 17.71 & 8.67 \\
\hline Lindane & 0.33 & 0.32 & 0.89 & 0.04 & 1.49 & 0.59 & 2.14 & 0.48 & 0.34 & 0.20 & 0.62 & 0.10 \\
\hline $\mathrm{HCB}$ & $<1$ & - & 1.92 & $<1$ & - & - & 9.12 & $<1$ & - & - & 7.75 & $<1$ \\
\hline Heptachlor & - & - & nd & nd & - & - & nd & nd & - & - & nd & nd \\
\hline $2.4 \mathrm{DDE}$ & 0.48 & 0.21 & 0.84 & 0.27 & 0.57 & 0.24 & 0.84 & 0.37 & 0.43 & 0.07 & 0.48 & $<0.2$ \\
\hline Cis \& Trans Chlordane & - & - & nd & nd & - & - & nd & nd & - & - & nd & nd \\
\hline Trans Nonachlor & 3.52 & 2.47 & 7.14 & 1.58 & 1.12 & 0.95 & 2.09 & 0.12 & 1.74 & 0.32 & 2.19 & 1.27 \\
\hline 4.4'DDE & 5.13 & 3.12 & 10.04 & 1.69 & 13.81 & 10.54 & 22.62 & 1.71 & 23.10 & 7.54 & 33.53 & 15.00 \\
\hline $2.4 \mathrm{DDD}$ & - & - & nd & nd & - & - & nd & nd & - & - & nd & nd \\
\hline 4.4'DDD & 1.44 & 0.63 & 2.50 & 0.97 & 3.75 & 3.20 & 6.01 & 1.48 & 2.01 & $0 . S I$ & 3.54 & 1.36 \\
\hline $2.4 \mathrm{DDT}$ & 1.64 & 1.65 & 4.68 & 0.19 & 1.1 & - & 1.1 & $<1$ & 0.78 & 0.41 & 1.54 & 0.42 \\
\hline 4.4'DDT & - & - & nd & nd & - & - & nd & nd & - & - & nd & nd \\
\hline$\Sigma$ TOT OCP & 12.46 & 6.10 & 22.27 & 5.70 & 23.82 & 17.56 & 38.34 & 4.30 & 29.45 & 9.33 & 40.49 & 18.68 \\
\hline$\Sigma$ TOT OCP on lipid basis & 44.84 & 21.94 & 80.17 & 20.52 & 85.75 & 63.23 & 138.04 & 15.47 & 106.01 & $33.5 \mathrm{~s}$ & 145.78 & 67.25 \\
\hline
\end{tabular}

-Recommented vahe: 200ng g' ww on lipid bæis. European Comuriss ion EC N"199/2506 (2006) 
Table 3. Comparison of the ratio between the $\sum P C B s$ and the sum of compounds CB28 and CB52 in sediment, suspended particles (SPM) from the downstream estuary, the upper estuary, one industrial discharge point and eel liver from the freshwater and downstream estuary.

\begin{tabular}{|c|c|c|c|}
\hline & \multicolumn{3}{|c|}{$\mathrm{Sum} P C B s /[\mathrm{CB} 28+\mathrm{CB} 52$} \\
\hline & $\mathrm{N}$ & mean & Std. Dev: \\
\hline \multicolumn{4}{|l|}{ Upper estuary } \\
\hline Sediment* & 4 & 2.6 & 1.3 \\
\hline SPM $^{*}$ & 3 & 3.6 & 0.5 \\
\hline Freshwater eels (muscle) & 9 & 5.1 & 2.1 \\
\hline Freshwater eels (liver) & 4 & 3.2 & 1.0 \\
\hline \multicolumn{4}{|l|}{ Lower estuany } \\
\hline Sediment* & 13 & 6.1 & 2.8 \\
\hline SPM $^{*}$ & 6 & 5.2 & 2.6 \\
\hline Industrial discharge point * & 3 & 14 & 6 \\
\hline Estuary eels (muscle) & 6 & 26.2 & 2.9 \\
\hline Estuary eels (liver) & 6 & 33.6 & 14.3 \\
\hline
\end{tabular}


Table 4. Percentage of eel from the Adour basin classified according to the four quality classes of Belpaire and Goemans (2007b) for $\mathrm{Cu}, \mathrm{Zn}, \mathrm{Cd}, \mathrm{Pb}$ and total $\mathrm{m}$ ercury $(\mathrm{T} \mathrm{H} \mathrm{g})$ in muscle. Quality classes were developed based on quantitative distribution of PCBs, OCPs and heavy metals. Not deviating class: unpolluted or low polluted sites; STightiy deviating class: slightly and moderately polluted sites; Deviating class and Strongly deviating class: sites with the more pronounced contam ination. SLG: St Laurent de Gosse.

\begin{tabular}{llccccc}
\hline Location & Quality class & $\mathrm{Cu}$ & $\mathrm{Zn}$ & $\mathrm{Cd}$ & $\mathrm{Pb}$ & $\mathrm{T} \mathrm{Hg}^{*}$ \\
\hline Termi $(\Lambda=51)$ & not deviating & 98 & 98 & 78 & 96 & \\
& $\begin{array}{l}\text { slightly deviating } \\
\text { deviating }\end{array}$ & 2 & 2 & 20 & 4 & \\
& & 0 & 0 & 2 & 0 & \\
SLG $(\Lambda=21)$ & not deviating & 95 & 100 & 62 & 95 & 0 \\
& slightly deviating & 5 & 0 & 38 & 5 & 100 \\
& deviating & 0 & 0 & 0 & 0 & 0 \\
Wholefreshwater & not deviating & 97 & 99 & 74 & 94 & \\
$(\Lambda=72)$ & slightly deviating & 3 & 1 & 25 & 6 & \\
& deviating & 0 & 0 & 1 & 0 & \\
Estuary $(\Lambda=20)$ & not deviating & 100 & 100 & 100 & 100 & 0 \\
& slightly deviating & 0 & 0 & 0 & 0 & 40 \\
& deviating & 0 & 0 & 0 & 0 & 60 \\
\hline
\end{tabular}

Cu: not deviating $\left(<600 \mathrm{ng} \mathrm{g}^{-1} \mathrm{w}\right.$ w); Cu: slightly deviating $\left(600<-<1600 \mathrm{ng} \mathrm{g}^{-1} \mathrm{w}\right.$ w)

$\mathrm{Zn}:$ not deviating $\left(<35000 \mathrm{ng}^{-1} \mathrm{w}\right.$ w); $\mathrm{Zn}$ : slightly deviating $\left(35000<-<88000 \mathrm{ng} \mathrm{g}^{-1} \mathrm{w}\right.$ w)

$\mathrm{Cd}$ :not deviating $\left(<5 \mathrm{ng} \mathrm{g}^{-1} \mathrm{w}\right.$ w); Cd: slightly deviating $\left(5<-<12,6 \mathrm{ng} \mathrm{g}^{-1} \mathrm{w} \mathrm{w}^{2}\right.$ ) Cd deviating $\left(12,6<-<31,7 \mathrm{ng} \mathrm{g}^{-1} \mathrm{w}\right.$ w)

$\mathrm{Pb}$ :not deviating $\left(<25 \mathrm{ng} \mathrm{g}^{-1} \mathrm{w}\right.$ w) $\mathrm{Pb}$ : slightly deviating $\left(25<-<63 \mathrm{ng} \mathrm{g}^{-1} \mathrm{w} \mathrm{w}^{\mathrm{w}}\right)$

T Hg ("based on Arleny et al., 2007): not deviating ( $<100 \mathrm{ng} \mathrm{g}^{-1} \mathrm{w} \mathrm{w}^{\mathrm{w}}$ ) $\mathrm{T} \mathrm{Hg}$ slightly deviating $\left(100<-<252 \mathrm{ng} \mathrm{g}^{-1} \mathrm{w}\right.$ w):

THg deviating $\left(\geq 252 \mathrm{ng} \mathrm{g}^{-1} \mathrm{w} \mathrm{w}\right)$ 


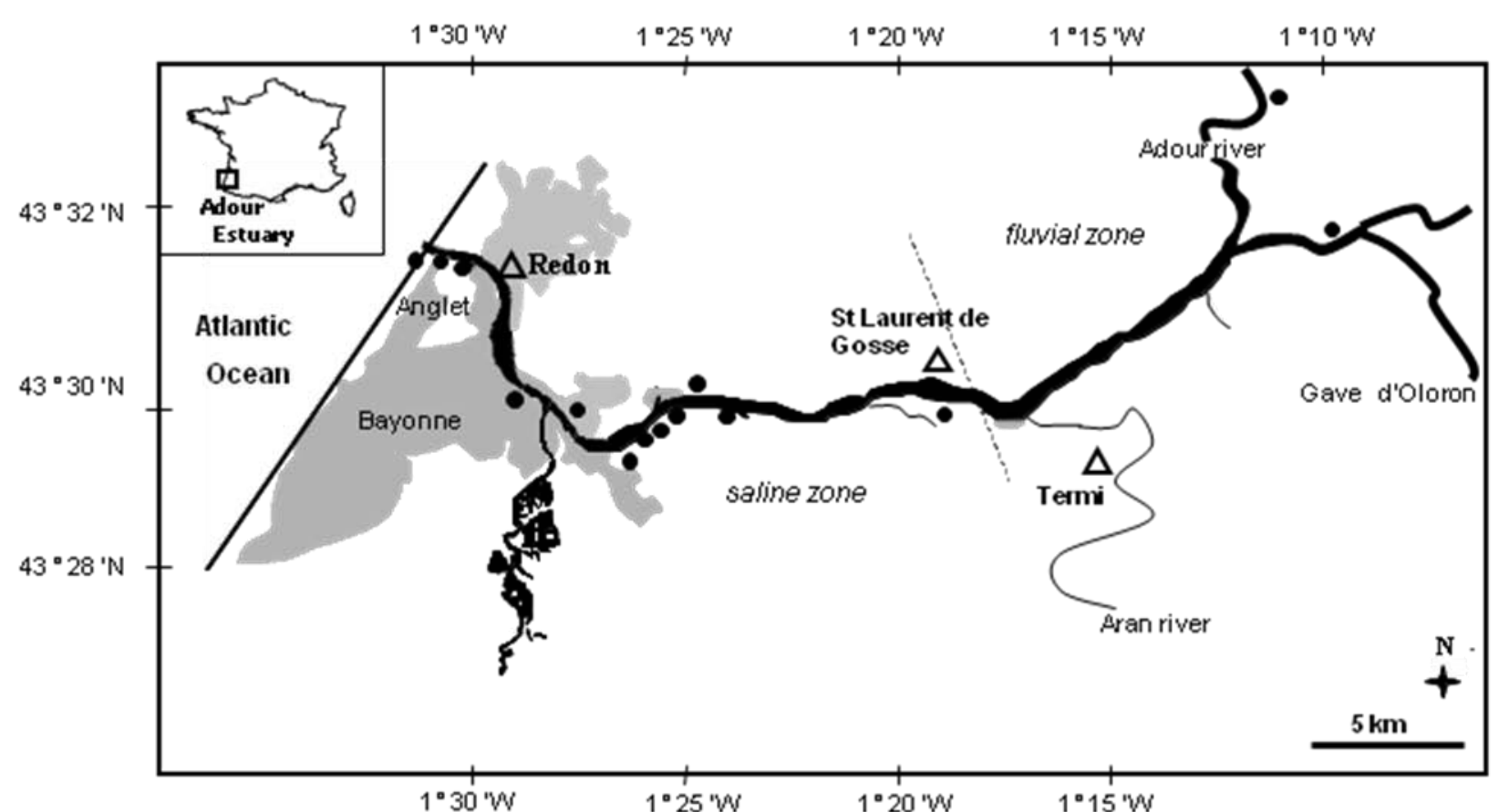

Figure 1. Map of the sampling site distribution on the Adour estuary. Black dots indicate water sampling and black triangles mark both yellow eels and water collection. 

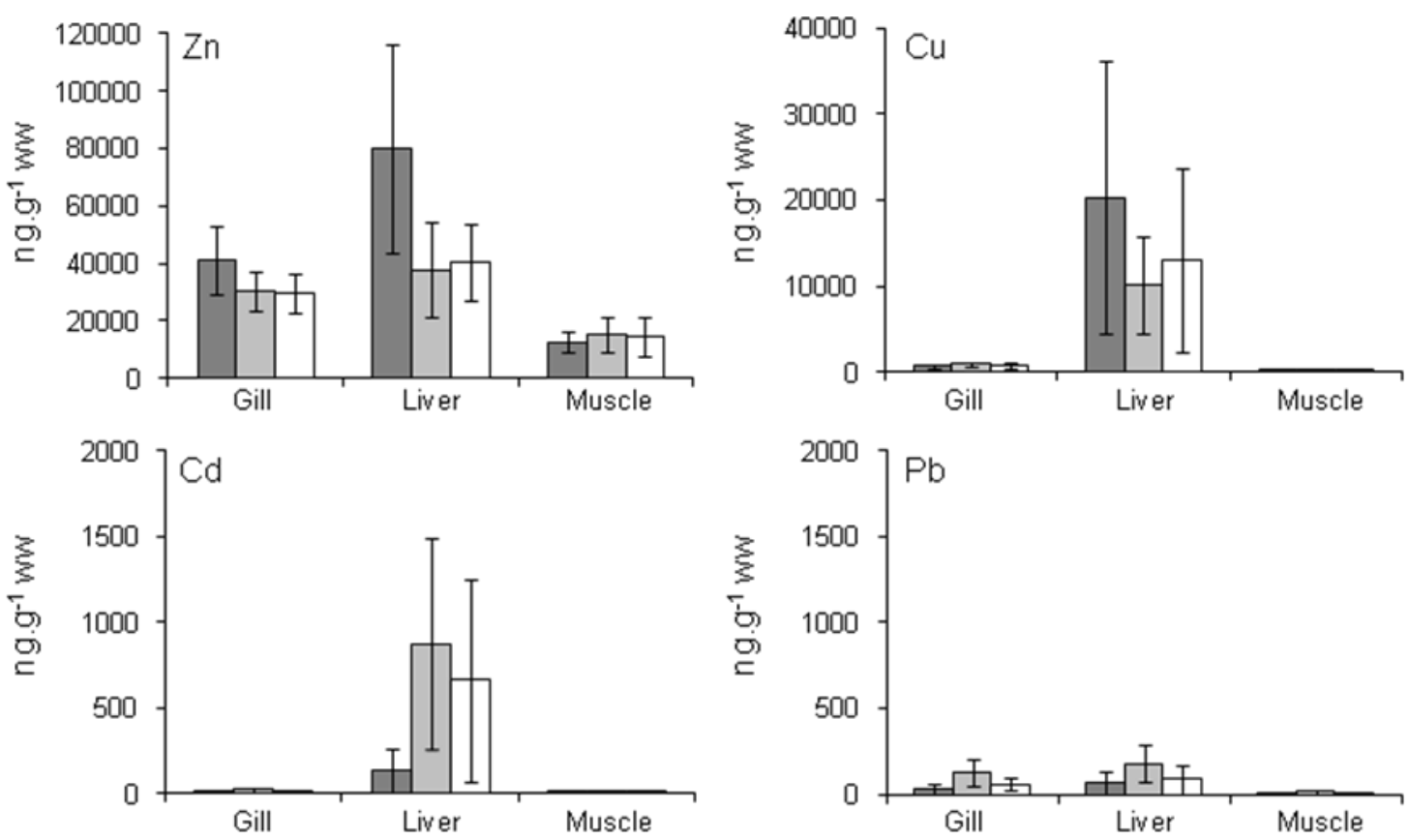

$\square$ Redon $\square$ SLG $\square$ Termi

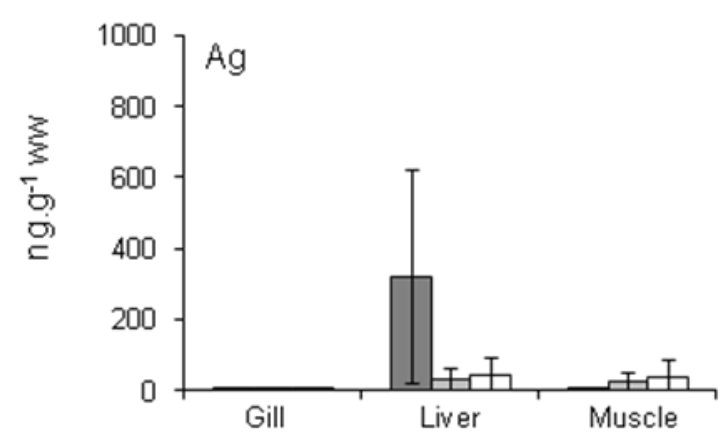

Figure 2. Mean concentrations (ng. $\mathrm{g}^{-1} \mathrm{ww}$ ) of $\mathrm{Cu}, \mathrm{Cd}, \mathrm{As}, \mathrm{Ag}, \mathrm{Zn}, \mathrm{Pb}, \mathrm{Sr}$ and $\mathrm{Ba}$ in gills, liver and muscle of yellow European eels from the Adour downstream estuary (Redon), St Laurent de Gosse (SLG) and Termi. Standard deviation are illustrated by double bars. 


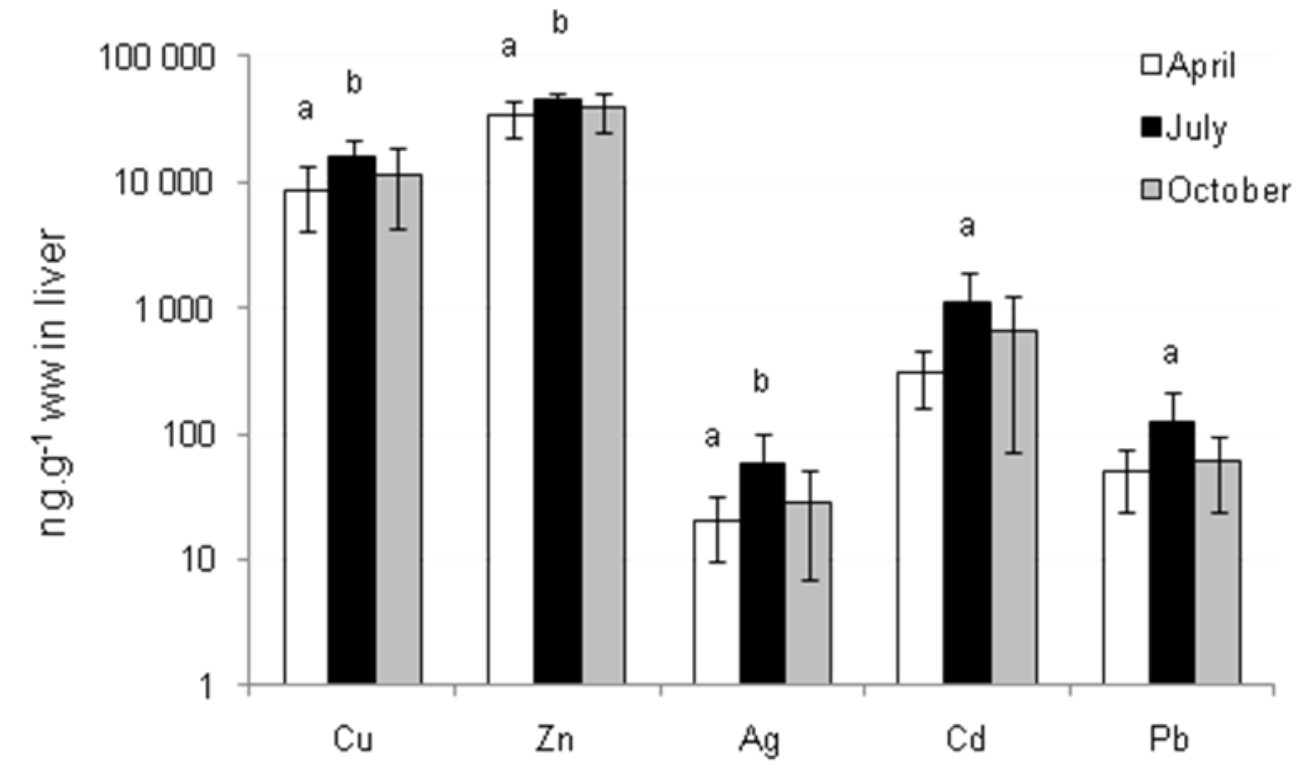

Figure 3. Average heavy metal concentrations in liver $\left(\mathrm{ng} \cdot \mathrm{g}^{-1} \mathrm{ww}\right.$ ) of yellow eels from Termi in April $(N=15)$, July $(N=9)$ and October $2006(N=10)$. Standard deviations are illustrated by double bars. Significant differences are indicated by letters. 


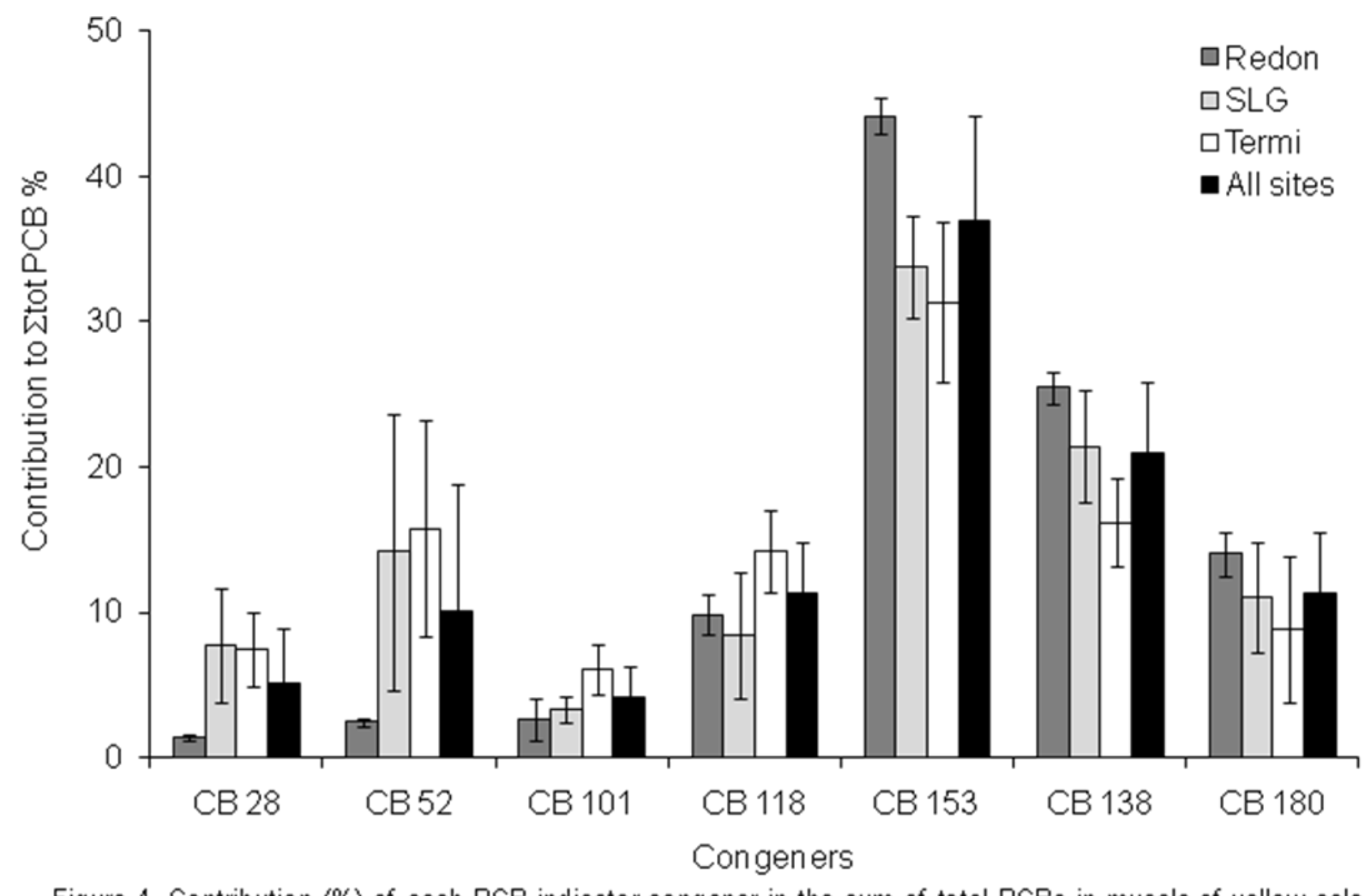

Figure 4. Contribution (\%) of each PCB indicator congener in the sum of total PCBs in muscle of yellow eels from the Adour estuary (Redon) and the two watersheds (Termi and St Laurent de Gosse SLG) and all sites. 


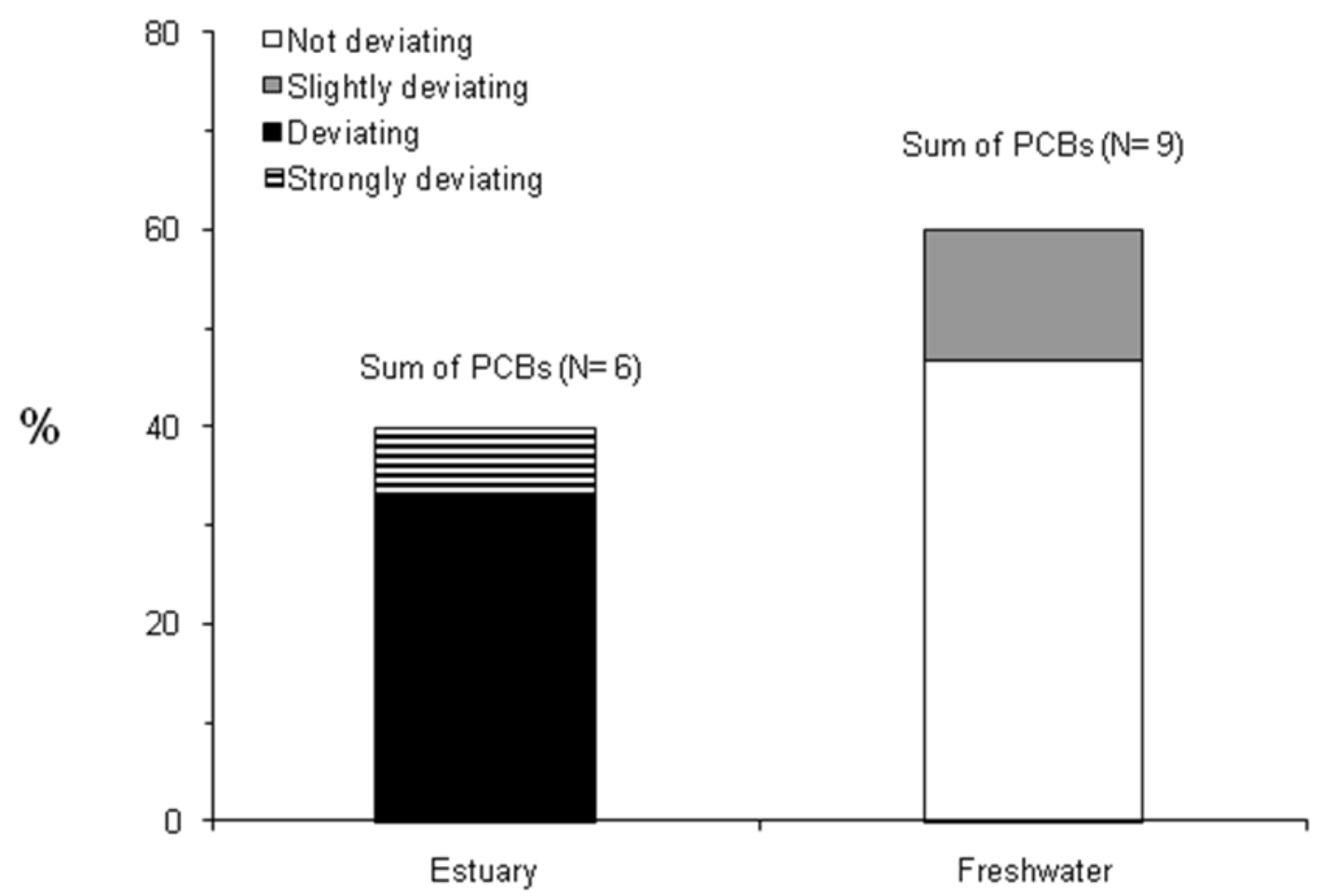

Figure 5. Percentage of eel from the estuary and freshwater sites classified according to the four quality classes of Belpaire and Goemans $(2007 \mathrm{~b})^{8}$ for the sum of the seven indicators PCBs in muscle. Quality classes were developed based on quantitative distribution of PCBs. OCPs and heavy metals. Not deviating class: sites unpolluted or low polluted $\left(<73 \mathrm{ng} \cdot \mathrm{g}^{-1}\right.$ ww); Slightly deviating class: slightly and moderately polluted sites $\left(73<-<183 \mathrm{ng} \cdot \mathrm{g}^{-1}\right.$ w.w); Deviating class (183<-<460 $\mathrm{ng} \cdot \mathrm{g}^{-1} \mathrm{mw}$ ) and Strongly deviating class (2 $460 \mathrm{ng} \cdot \mathrm{g}^{-1} \mathrm{ww}$ ): sites with the more pronounced contamination. 